\title{
The ordoliberalisation of the European Union?
}

Nedergaard, Peter

Published in:

Journal of European Integration

DOI:

10.1080/07036337.2019.1658751

Publication date:

2020

Document version

Early version, also known as pre-print

Citation for published version (APA):

Nedergaard, P. (2020). The ordoliberalisation of the European Union? Journal of European Integration, 42(2), 213. [4]. https://doi.org/10.1080/07036337.2019.1658751 


\section{Journal of European Integration}

\section{The ordoliberalisation of the European Union?}

\section{Peter Nedergaard}

To cite this article: Peter Nedergaard (2020) The ordoliberalisation of the European Union?, Journal of European Integration, 42:2, 213-230, DOI: 10.1080/07036337.2019.1658751

To link to this article: https://doi.org/10.1080/07036337.2019.1658751

曲 Published online: 10 Sep 2019.

Submit your article to this journal $\pi$

Џlll Article views: 244

Q View related articles $\widetilde{ }$

View Crossmark data ¿ 


\title{
The ordoliberalisation of the European Union?
}

\author{
Peter Nedergaard \\ Department of Political Science, University of Copenhagen, Copenhagen, Denmark
}

\begin{abstract}
For the first time, this paper investigates the influence of ordoliberalism (OL) at both the ideational and regulative levels of European integration processes regarding agricultural policy (i.e. (AP), competition policy, and economic and monetary policy (i.e. $\mathrm{EMU}$ ) in comparison. The analytical key is an operationalisation of $\mathrm{OL}$ into five elements. The paper generally confirms the hypotheses proposed that $\mathrm{OL}$ was and remains an ideational influence of some importance, without exaggerating this influence, for European integration processes, both at the constitutive level as well as - but less so - at the practical level. However, there are differences in the degree of influence across the various policy areas. The influence is weakest in CAP and strongest in competition policy, but only since the Internal Market was proposed in the mid-1980s.
\end{abstract}

\section{KEYWORDS}

Ordoliberalism; European

Union; CAP; competition

policy; EMU

\section{Introduction}

Can the ordoliberal school of thought contribute to a better understanding of the particular set-up of the policies of the European Union? Christian Joerges has argued that the Treaty of the European Economic Community (EEC) of 1957 was based on the key idea that the it should establish 'the interdependence of a system of undistorted competition, individual freedoms and the rule of law - and protect this precious balance against discretionary political influence' (cf. Oksala 2017, 191). This seems consistent with the theoretical framework underlying ordoliberal governance that has dominated (West) German political decision-making after the Second World War. Is the European Union (EU) then also dominated by so-called 'politics by rules' ${ }^{1}$ of the ordoliberal type?

Could one even postulate that the EEC is an ordoliberal-type European economic constitution? In addition, are the practices of the various EU policies consistent with ordoliberalism (OL)? In many ways, the new transnational order of the EU was attractive for OL. It meant the opening of economic transactions across the Community, the political establishment of a common market, and later an Internal Market based on the principle of undistorted competition within a specific political frame.

However, whether or not the EU is a materialisation of ordoliberalism (OL) is more complicated. Another influential line of thought in the 1950s was planification, which was commonplace among the founding member states in all sectors of the economy. EU 
founding father Jean Monnet was director of the French Planning Commission. The EU did not suddenly come to conform to the OL playbook in its entirety (cf. also Joerges 2017). Nevertheless, it is worth investigating whether there were and are indices of $\mathrm{OL}$ influences on the European integration processes and the practical policy processes herein.

In the scholarly literature, $\mathrm{OL}$ is generally recognised as being a powerful economic philosophy framing the thinking of post-World War II Germany's political decisionmakers (Feld, Köhler, and Nientiedt 2015; Goldschmidt and Rauchenschwandtner 2007; Vanberg 2004; Walters and Haahr 2005). In recent years, the renewed relevance of OL stems from a postulated relationship between OL and the politics of austerity in the EU (Biebricher and Vogelmann 2017; Nedergaard and Snaith 2015). However, this economic philosophy has also been recognised as the source of ideational influence (to a greater or lesser extent) on European integration processes in other policy areas (Dullien and Guérot 2012; Foucault 2008; Joerges 2017), even though there are surprisingly few studies of this latter aspect.

In this article, I do not conclude definitively about any causal relationship between OL and concrete European integration steps. I argue for the existence of indices for a causal relationship between the independent variable $(\mathrm{OL})$ and dependent variable (various concrete or practical EU integration steps) via a mediating variable (the constitutive principles of EU integration). I claim that there are indices of OL influence if - and when - the OL and selected EU policies correspond to each other and if the prescripts of OL correspond to EU policy practices.

One might argue that the traces of OL I find in the EU are merely indicative of German influence because Germany is, at least in recent years, the most powerful EU member state. This might be true even though there is far from a 1:1 correspondence between the actual German government positions and normative OL recommendations. However, even though German influence is what I largely find when applying this methodology, I will argue, with reference to various scholarly sources, that such an influence comes mostly dressed up as OL. Distinguishing between German and OL sources of potential influence is therefore pointless.

In the next sections, I analyse OL before examining the following phenomena of the EU compared to OL: the Common Agricultural Policy (CAP), the Competition Policy, and the Economic and Monetary Union (EMU). These policy phenomena are selected due to their being most likely (competition policy), neither most nor least likely (EMU), and least likely (CAP) cases of political ideational influence stemming from OL. Finally, I conclude.

\section{What is ordoliberalism?}

OL emphasises that the constitutive economic order is interdependent with all other 'orders' in society, including judicial, social and political. The basis for a successful economic policy is the establishment of a strong legal and institutional framework, referred to in the OL tradition as a set-up based upon 'politics by rules' (see in endnote 1 why Ordnungspolitik in this article is translated in this way) (Eucken 1940; Bonefeld 2017). Ordnung ('order' or ordo in Latin) is, or ought to be, related to an economic constitution in the sense of the rules of the game upon which economic market systems 
are based. The fact that OL is both 'is' and 'ought' illustrates that it is both an analytical theory and a political programme (Vanberg 2004).

OL involves two groups of principles: constitutive and regulative (or principles of policy practices). In both cases, the main instrument (or 'technology' in Foucault's terminology) is the law. The constitutive principles manifest themselves as 'an economic constitution' (Wirtschaftverfassung). The regulative principles manifest themselves as the maintenance of the functioning of the competitive order (Eucken 1952). The original idea in OL is the investigation of the specific relationship between these two sets of principles.

In $\mathrm{OL}$, the most important condition for the functioning market is no longer free exchange, as in classical liberalism; rather, in $\mathrm{OL}$ it is 'free, full and complete competition'. Free competition is not a pre-given foundation of society that should merely be allowed to rise to the surface. It is a politically constructed structure with formal properties (Oksala 2017).

The centrality of competition in ordoliberal governance has profound consequences: free competition always entails winners and losers. Free markets are unequal, antagonistic and conflictual, whereas a free exchange approach in classical liberalism is harmonious at the conceptual level.

For ordoliberals, it is normatively important that the abovementioned antagonisms are not politicised. The state must act as a neutral referee of the market game, and it is an important 'constructor' hereof. The goal of ordoliberal governance is thus a depoliticised society in which individuals compete against each other as entrepreneurs, not as political actors. However, the depoliticisation of society must itself be understood as an eminently political practice (Oksala 2017). In the EU, depoliticisation as recommended by OL (but, again, not necessarily caused by OL) - means that many basic EU economico-political decisions should principally be removed from democratic, political decision-making, instead being executed through legal instruments and by unelected economic experts (cf. Young 2010, 56-57). Apparently, this was a method used from the beginning of the European integration process, as noted by one of the founding fathers of European integration research, Ernst B. Haas. In his seminal book 'The Uniting of Europe', he states: 'Therefore, measures of integration resulting in the setting up of federal "technocratic" or "detached expert" organs, separate from both state and economy, are welcomed' (Haas [1958] 2004, 22).

This article refrains from delving deeply into the origins of $\mathrm{OL}^{2}$, but it needs to be mentioned that OL is a theoretical school of German offspring (Hutchinson 1981) and essentially appears to be a German 'invention'. Not many direct influences from other sources can be discerned aside from some minor ones from the Austrian School of Economics, with Ludwig van Mises and Friedrich A. von Hayek as leading figures (Vanberg 2004). According to Dullien and Guérot (2012), most German economists have at some point in their careers been influenced by OL. Its influence on top German decision-makers was also confirmed in a series of interviews I conducted in 2014 (see Nedergaard and Snaith 2015).

In practical terms, $\mathrm{OL}$ is claimed to be the economic philosophy behind the successful post-World War II German social model (Goldschmidt and Rauchenschwandtner 2007; Vanberg 2004). Ludwig Erhard, the father of the German Wirtschaftswunder (as well as being the former minister of finance, Bundeskanzler, and professor of economics), was an explicit proponent of OL (Hutchinson 1981). The assumption of this article is that the 
excellent economic performance and position of Germany in most years since World War II might have given weight to the ideas behind OL in terms of how various EU policies were constructed and have developed over the years (cf. also Dullien and Guérot 2012).

The original OL School included Walter Eucken (the primary figure), Franz Böhm, Hans Grossmann-Doerth, Alexander Rüstow, and Wilhelm Röpke. OL was explicitly interdisciplinary from the outset, with representatives educated in economics, law and philosophy. OL claimed science alone to be capable of developing an accurate analysis of the multiple interdependencies of modern societies. Implicitly and originally, OL scholars called for a rather (liberal) authoritarian and strong state, ideally informed by the 'men of science' (a concept from the original Ordo Manifesto of 1936) (Eucken, Böhm, and Grossmann-Doerth 1936). At the same time, according to OL, the social sciences also have a normative responsibility to inform political decision-making (Biebricher and Vogelmann 2017a). Haas noted in 1958 that 'Alexander Rüstow, for instance, has argued that the economic integration of Europe through schemes such as ECSC is a desirable step for maximising the natural geographic advantages of certain industries and thus rationalise patterns of distribution [...]. His ideological colleague in Bonn's Ministry of Economics, Ludwig Erhard, has been consistent defender of the same principles ...' ([1958] 2004, 21-22).

It is of crucial importance that the 'politics by rules' does not intervene directly into markets but must only be directed at market frameworks; that is, through the constitutive principles (in the form of the economic constitution), which signify that the meaning hereof goes beyond a written constitution (Biebricher and Vogelmann 2017a). In OL, an economic constitution is the technical instrument for ordering the economy, but it is also the goal to be reached via the ordering of the economy. The rules of an economic constitution are explicit and rigorous, and are the preferred technique of ordoliberal governance (Böhm 1937). In an ideal OL world, the state would never intrude directly into economic processes. As to the relationship between the economic and political constitutions, the technical part of an economic constitution is proportionally far greater than in the case of the political constitution. In this sense, both the original Treaty of the European Economic Community and the present Lisbon Treaty bear some similarities with an economic constitution.

Foucault (2008, ch., 4-6) analysed OL in his College de France lectures 1978-79. According to him, OL broke with the preceding tradition of liberalism in denying that the political consequence of free markets should be laissez-faire. OL thus represents a novel form of governmentality, and it necessitates and rationalises a specific technology of power. Foucault claims that OL generally rethought the relationships between economy and politics. This happened through its theory of the economic constitution mentioned above, which guarantees and respects the system of undistorted (free, full and complete) competition, economic and personal liberties, and state requirements under the rule of law (Joerges 2017).

Consequently, according to $\mathrm{OL}$, the market is defined by its institutional set-up and, as such, subject to the choices of political decision-makers. In other words, an economic order is subject to human design and decision-making: the market is a construction. This anti-naturalistic assumption of the market stands in stark contrast to laissez-faire liberals, who often refer to it as an almost God-given economic reality (Walters and Haahr 2005). Conversely, for ordoliberals, decision-makers are responsible for a strong state, which 
can actively create the conditions under which the 'invisible hand' (as described by Adam Smith) can be expected to function (Nedergaard and Snaith 2015; Vanberg 2004).

In the view of OL, the free market forces therefore require careful 'cultivation' for their maintenance and proper functioning (Vanberg 2004). Where ordoliberals use gardening as a metaphor for what political decision-makers of the state should do vis-à-vis the market, some laissez-faire liberals preferred the night watchman as a metaphor for the state (i.e. nothing except turning on the lights at night). In contrast, interventionist state theorists often refer to an engineer (cf. the concept of 'social engineering').

The notion that a strong state should serve as the guardian of the competitive order stands in contrast to liberalism, as represented by Friedrich A. von Hayek (1960, 221). He stressed that 'the method of specific orders and prohibitions', which might be necessary for the 'cultivation' of the market forces according to $\mathrm{OL}$, is ruled out, as a matter of principle, by the liberal concept of

'spontaneous market order'. In other words, the freedom of contract (as hailed by Hayek) cannot be accepted by ordoliberals to undermine the market through cartel agreements, beggar-thy-neighbour devaluations, and so forth (Eucken 1940; Vanberg 2004).

In contrast to this view on cartel agreements, one of the founding fathers of neoliberalism, Murray Rothbard, sees no reason to object to cartel contracts; from his perspective, they are nothing but voluntary contracts among producers. 'To regard a cartel as immoral or hampering some sort of consumer sovereignty is therefore completely unwarranted' (Rothbard 1970, 570).

The primary figure of $\mathrm{OL}$, Walter Eucken, stressed that a strong state is obliged to create a stable economic and monetary policy and avoid large public deficits. The principles of $\mathrm{OL}$ in this regard differ from Keynesian demand management: the government should attempt to replace continuous Keynesian fiscal policy exercises with solid, predictable, and autonomous economic institutions (Hutchinson 1981). Consequently, in contrast to laissez-faire liberalism but in line with interventionism, ordoliberals have always claimed that, working alone, the business community can never be trusted to serve the common interest because it might promote narrow business interests at the expense of broader common interests (Eucken 1940).

Instead, according to Eucken, at the level of regulative principles, 'politics by rules' first and foremost implies a policy aimed at securing a competitive process that works for the benefit of consumer interests. It should always pursue consumer sovereignty to the greatest possible extent, precisely because the consumer is the representative of the common interest in OL philosophy and the actor towards whom all economic political decisionmaking should be directed - in contrast to policies favouring special interests.

Table 1 below summarises the key concepts mentioned above and briefly states how I apply them in my analysis of the various EU policies: my bid for the content of OL as far as the subject of this article is concerned.

\section{OL and European integration initiatives}

(1) The Common Agricultural Policy (CAP)

In his College de France lectures, Foucault $(2008,141)$ claimed that the CAP was quintessentially $\mathrm{OL}$ from the beginning: 'What is more, you see in passing that this 


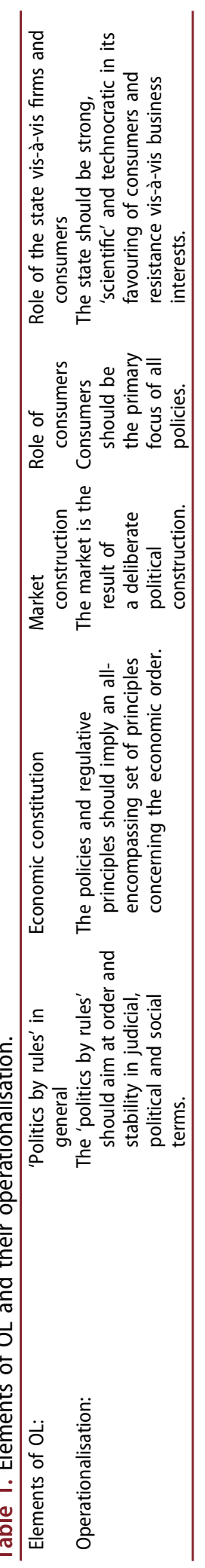


1952 text (by Walter Eucken, author) programs, even if in a completely rough and ready way, what will become the Common Agricultural Market of the next decade. The text is from 1952. The Mansholt plan (which was the conceptual basis of the CAP, author) is already in Eucken, or it is part in Eucken, in 1952.'

Generally, according to Foucault, the OL's conceptualisation of the market is a novelty worth analysing. It introduces a much more activist agenda than neoliberalism and laissez-faire liberalism, and the distinction between state and market as autonomous entities no longer holds in the OL model; instead, they are mutually intertwined. Markets have to be constituted by the political level. As mentioned by Foucault, there is a strong parallel in the constitutive and regulative principles of the CAP (cf. Nedergaard 2006a). The main technologies of governing the EU's agricultural markets are EU regulations and EU directives, i.e. EU law. It is a matter of making the market for agricultural produce and competition - and so the enterprise - into what could be called the formative power of society (cf. Foucault 2008).

Analysis of the CAP from an OL perspective can begin with how the Treaty of Rome provided it with contradictory objectives (or principles), with no priority ordering of them (Grant 2018). These objectives (in the OL language: constitutive principles) have not been revised in subsequent treaties, although it should be noted that the implicit policy objectives have changed, particularly in the direction of an 'environmentalisation' of the CAP. New policy instruments (regulative principles, in OL terminology) have also been devised to replace earlier instruments that led to a number of problems, including large surpluses of certain products held in storage (Grant 2018; Nedergaard 2006b).

Five of the CAP objectives were set out in the EU's economic constitution in Article 39(1) of the Treaty of the European Economic Community. The underlying theme was the construction of a pan-European marketplace for agricultural produce with free and full competition. The first objective was concerned with increasing agricultural productivity through the promotion of technical progress and the optimum utilisation of factors of production. Technical progress has been achieved over the years, but not so much as a result of EU policy as of exogenous technical (not least American) innovations, such as pesticides, even though the principles of the CAP then pushed the productivity upwards through the 'overconsumption' of productive means (Grant 2018; Nedergaard 2006a).

The second objective was to ensure a fair, stable standard of living for the agricultural community, particularly by increasing the individual earnings of those engaged in agriculture. There was concern that the disparity between urban and rural incomes in Europe might contribute to social unrest and disorder. The gap between agricultural and other incomes was not eliminated and has remained a source of concern for policymakers for much of the time in which the CAP has existed (Grant 2018; Nedergaard 2006a). The agricultural subsidies of the CAP were an inefficient mechanism for tackling this problem, particularly given that the estimated distribution of subsidies followed a Pareto rule, with $80 \%$ of the payments going to $20 \%$ of farmers (Commission 2017, 18; Grant 2018).

The third objective of the CAP was to stabilise markets. From an OL perspective, this was an important integration of a component of orderly 'politics by rules' in the CAP. Agricultural markets are subject to cyclical price fluctuations, partly due to the effect of weather on supplies. However, the use of intervention pricing to provide a market floor encouraged farmers to overproduce, as they knew there would be a market for their 
produce above the marginal cost of production, leading to the infamous 'butter mountains' and 'wine lakes' (Grant 2018).

The fourth objective was to ensure a secure supply for European consumers. Market failures potentially imply a fundamental insecurity in the production of agricultural goods (Nedergaard 2006a). This has been achieved in the sense that exports have increased while imports of temperate products have been reduced; exports gradually exceeded imports. The security, however, has partly been achieved by raising high external tariff barriers leading to increased agricultural produce prices within the EU.

The CAP tariff barriers have also affected the fifth objective: ensuring that supplies reach consumers at 'reasonable' prices (Grant 2018). While this is an important component in an OL consumer interest perspective, much depends on how 'reasonable price' is defined; nevertheless, tariff protection has pushed food prices in the EU above world market prices. Hence, even though consumers were an important part of the CAP objectives - as the ordoliberals also wanted - in reality, there was more an accommodation of the agricultural business interests. This was also present through 'open doors' interest lobbyism in relation to CAP decision-making, which was and is at odds with OL (Nedergaard 2006a).

The CAP has been reformed, largely in response to budgetary and international trade negotiation pressures in GATT and WTO. At one point in the 1970s, it accounted for over twothirds of a per cent of the EU budget and threatened to break the budget in the early 1980s, leading to a number of changes in the regime for the expensive dairy sector, particularly in the form of quotas to restrain production. In response to the Uruguay Round trade negotiations, the 1992 MacSharry reforms represented an important step forward, introducing a system of area-based subsidies in the arable sector (Nedergaard 2006b).

These reforms were taken a step further by reforms introduced by Commissioner Franz Fischler in 2003 (Nedergaard 2006b). A central change was the introduction of the Single Farm Payment, now known as the Basic Payment, based on historical entitlements. This decoupled a large share of CAP support from production and meant that farmers were no longer incentivised to overproduce in order to claim their subsidy payments. Today, such direct payments account for over $70 \%$ of the CAP budget (Grant 2018). As can be seen, the price floor has been more or less eliminated, which is to the benefit of consumers; however, the farmers have kept much of their support from the EU due to successful lobbyism, but it has been transformed from indirect price subsidies paid for by consumers to direct subsidies paid for by tax payers (Nedergaard 2006a). Table 2 on page 9 summarises the elements of $\mathrm{OL}$ and their operationalisation in relation to the CAP.

In conclusion, there is only partial correspondence between the $\mathrm{OL}$, the principles of the CAP, and the CAP practices.

\section{(2) Competition Policy ${ }^{3}$}

Walter Eucken considered the economic policy of laissez-faire liberalism to be incompatible with the principle of the rule of law (Rechtsstaat), as this form of liberalism without order always threatened to harm society as a whole, not least via cartels and monopolies (Hutchinson 1981). The laissez-faire principle does not create a competitive order; other principles are required (Eucken 1952). Basically, his central hypothesis from the beginning of the OL era was that monopolies and lack of competition have nothing to do with 


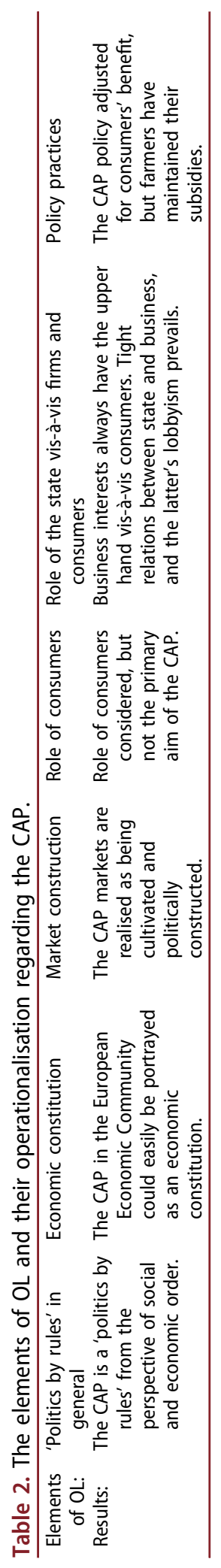




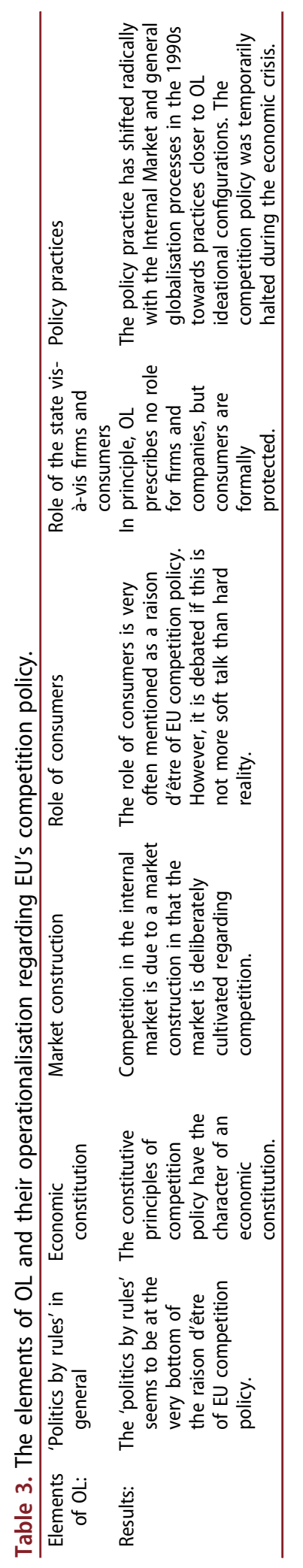




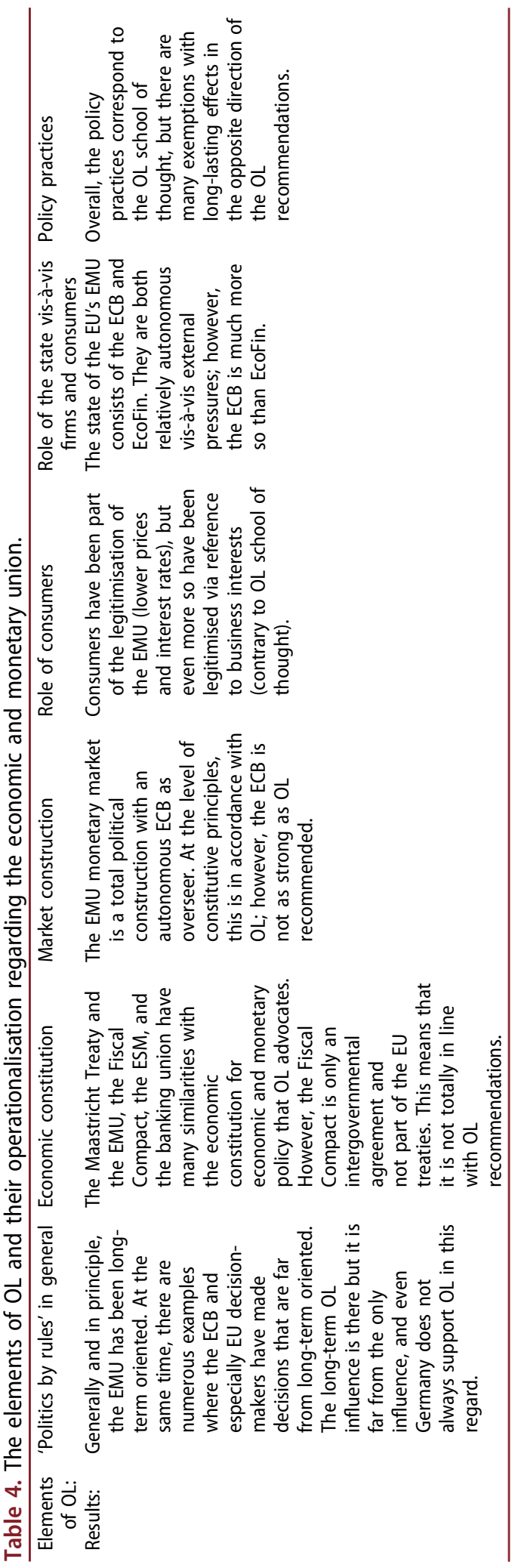


capitalism itself, but rather a particular 'organization of peoples in state and society' that 'seriously obstructs the functioning of the capitalist mechanism, limiting or even making its development impossible' (Eucken 1932, 55). Monopolies result from the distortive effects of interest-driven economic policy on markets and competition between private companies. According to OL, monopolies should be replaced by a competitive order with benefits for the consumers (Eucken 1932).

Hitherto, the influence of OL on the EU's competition policy has been studied through interviews with the founding fathers of European integration as well as research on the negotiations that led to the articles of competition policy in the European Coal and Steel Community. There are more or less well-founded assumptions about such influence (Akman and Kassim 2010; Fejø 2009; Walters and Haahr 2005). Instead, as mentioned in Table 1, I use a number of elements as a measure of influence that might or might not be there.

In Europe, there was a lack of experience with competition policy until the 1950s. The first European law on competition policy, the German Gesetz gegen Wettbewerbbeschränkungen, was implemented in 1957. In other words, the competition policy in the Coal and Steel Community from 1953 was founded and co-evolved in parallel to the national competition policies (Akman and Kassim 2010). The EU competition law was basically inspired by US antitrust regulations. In the eyes of the US government, German monopolies (e.g. IG Farben, Vereignigte Stahlwerke, Krupp, BASF) had been too co-opted by the National Socialist regime and were therefore partly responsible for the atrocities of World War II (Walters and Haahr 2005, 50-52). At the same time, as stated by Buch-Hansen and Wigger (2010, 29), most governments 'were not favouring strict EC level competition regulation along ordoliberal lines'.

At the overall level and in line with general OL thought and also with American antitrust regulations, the EU competition policy at the level of constitutive principles follows the concept that if the market is left to itself, there is a risk of various developments undermining competition. More concretely, EU competition policy traditionally covered 1) anti-trust measures and the fight against cartels (Article 101 TFEU) and dominant positions (Article $102 \mathrm{TFEU}^{4}$ and 2) state aid (articles 106 to $108 \mathrm{TFEU}$ ). In recent decades, mergers (Regulation No. 4064/89 and No. 139/2004) have also come under the regulative principles of EU competition policy. The adoption of the 1989 Merger Control Regulation gave the Commission the authority to control mergers that met specified size and multi-nationality conditions. Before this, however, some merger regulation was based on the general articles of the treaties. The famous Continental Can ruling by the European Court of Justice (ECJ) paved the way for this juridical activist extension of EU jurisprudence (Nedergaard 2013).

In accordance with the OL 'strong state' concept (Bonefeld 2017), in principle, the Commission's Directorate-General for Competition plays a strong, 'state-like' role as overseer in the implementation of the EU competition policy (even though the EU is not a state, cf. Hix 1999). According to the treaties, the Commission may investigate rules on their own initiative or on receiving complaints. It can force firms to hand over documents and it can carry out raids on companies without prior warning (Walters and Haahr 2005). After an investigation, it can order enforcement or impose a fine. The ECJ (or the Court of First Instance) is responsible for appeals. 
However, the Commission only potentially represents a strong state in the competition policy field. As argued by Akman and Kassim (2010, 120) quoting Gerber, the Commission 'elected not to enforce vigorously the provision of state aid, government monopolies and government facilitation of private anti-competitive conduct in the foundational period' (Gerber 1998, 357-8). It was only with the launch of the Internal Market programme that the Commission directed attention to government interference in competition (Gerber 1998). In the period leading up to the Internal Market, the interventionist policy with considerable state aid and untouched government monopolies were popular among EU member states.

In 2004, as a prolongation of the Internal Market programme and general globalisation processes, the EU competition policy was reformed and a more effective division of tasks was proposed whereby the Commission, national competition authorities and national courts should share responsibility for enforcing EU antitrust rules (Nedergaard 2013). The Commission should hereafter focus on the infringement presenting the greatest risk of distortion at the EU level. One might speculate as to whether the 2004 reform was a sign of a stronger ordoliberal EU competition policy or one less so. Most signs seem to point in the first direction. For example, in cartel cases the Commission has imposed the largest fines in recent years. Conversely, there was a deliberately more relaxed attitude to state aid during the economic crisis in 2008 through to 2012, when it eased up on state aid rules and introduced a temporary framework allowing governments to grant loans and state guarantees and direct aid to banks and companies. This opened the way for a much more interventionist, competition-distorting policy in the state aid field. This state aid policy was extended in 2010 for one year and then phased out (Nello 2012, 373).

Generally, the OL version of economic freedom is that it should be 'orderly'. This seems to have been part of EU competition policy right from the beginning; however, it has been more strongly embedded in the rhetoric of the EU decision-makers only since the Internal Market programme was adopted, and especially since the globalisation processes came up to speed in the 1990s. Since then, large firms have had to behave 'as if' they were subject to market competition (Walters and Haahr 2005, 50-55).

EU decision-makers, for example, stress à la OL that '[w]ithout a solid competition policy [...] the European economy would descend into chaos' (statement by the former Competition Commissioner, Neelie Kroes in Akman and Kassim 2010, 17). In 2009, Kroes suggested that 'we need a clear level playing field for European consumers and businesses, not a jungle. But a jungle is what we would get if we suspended or abandoned competition policy' (Akman and Kassim 2010, 110). Here, a 'jungle' and 'chaos' can mean both a market without EU competition regulations, i.e. laissez-faire liberalism, as well as a market being the victim of interventionist and competitiondistorting national measures (Clift 2008).

To this, Akman and Kassim $(2010,118)$ point out that the prioritising of the consumers has been a

constant myth of EU competition policy since 1958. They provide many references, such as that

- according to the Commission report on the EC's General Affairs from 1988 - without an EU 
competition policy 'there is a risk that the Community consumers would be unable to enjoy the promised benefits of a large market'. The general view of the decision-makers behind the Internal Market programme was that consumer protection violations resulted from internal market failures. Table 3 on page 10 summarises the elements of OL and their operationalisation in relation to the EU's competition policy.

In conclusion, there is strong correspondence between the OL principles and EU's competition policy. There are indices of influence. However, the correspondence is less strong when it comes to policy practices. In any case, a correspondence first becomes a significant reality after the Internal Market programme and globalisation processes of the 1990s.

\section{(3) Economic and Monetary Integration ${ }^{5}$}

Walter Eucken was highly critical of Keynesianism and its idea that expansionary fiscal policy should solve the economic crises and fulfil the goal of full employment. In principle, he regarded it as a theory without order, in the sense that it set no limits to how expansionary fiscal policy could be. Thus, there was always a serious risk of Keynesianism entailing permanent public deficits (Dyson 2009). According to Eucken, the state is not responsible for ensuring full employment, but should provide the framework, stability and predictability to enhance the possibility of this goal being met. Moreover, an intact monetary system was of utmost importance for functioning markets. There should be no devaluations (Eucken 1952). At the more practical level of 'politics by rules', monetary policy decisions should aim at price stability and central bank independence, which are key elements in establishing order in the monetary field (Dullien and Guérot 2012).

The critical juncture of EU economic and monetary integration came when the EMU was established in the aftermath of the adoption of the Maastricht Treaty of 1992. The institution of the EMU was designed along OL lines. However, it was not the only ideational inspiration behind the EMU institutions. In addition, rule-based EMU originates in New Institutionalized Economics (Joerges 2017). At the practical policy (or regulative principles) level, the EMU presupposed the harmonisation of the economic and monetary policy of the EU member states and involved the introduction of a single currency in the form of the euro.

The EMU accession criteria consisted primarily of the requirement of a maximum of $60 \%$ of accumulated government debt-to-GDP ratio and annual public budget deficit of a maximum 3\% of GDP. In order to ensure that the criteria were met after EMU accession, the Stability and Growth Pact was adopted. The Maastricht Treaty accession requirements have thus been made permanent. The Stability and Growth Pact implies that the EcoFin is continuously assessing the performance of EMU countries in order to ensure that they comply with the prescribed criteria.

In the event of a drastic increase in unemployment, for example, the EcoFin ${ }^{6}$ can opt to accept the violation of criteria. In other cases, through an interest-free deposit or fine, it can sanction countries failing to comply with the Pact. Despite the numerous violations of the Stability and Growth Pact since its introduction, sanctions have yet to be practised at the level of regulative principles. The Maastricht Treaty was severely 
criticised by the German protagonists of OL 'politics by rules' for being too 'loose' on sanctions (Biebricher and Vogelmann 2017a).

On 1 January 2002, the euro was physically introduced as the currency of 12 of the then 15 EU countries: Germany, France, Italy, Belgium, Luxembourg, the Netherlands, Ireland, Greece (one year later), Spain, Portugal, Austria and Finland. This was quickly followed by the import of low German interest rates in many Southern European member states, which resulted in a boom in consumer spending and construction. From 2008 onwards, the Eurozone crisis came into focus. While triggered by the international financial crisis, it also had internal, EMU-related causes.

The EU economy had already started slowing down in 2002, and the Stability and Growth Pact came under attack for being much too rigid. By late 2002, the Commission had initiated the excessive deficit procedure for France and Germany, aiming at potential sanctions. At the level of regulative principles, Germany, supported by France, favoured revising the Commission's (OL) recommendations. This dispute caused deadlock in EcoFin as a qualified majority could not be found for a decision. Instead, a qualified majority in EcoFin annulled the sanctions of the Stability and Growth Pact against France and Germany. The European Central Bank (ECB) warned against this de facto suspension of the Pact, claiming that it was against the OL policy line. At the time, Greece had already violated the Pact and has been doing so since. Italy, Austria and Belgium have also violated the Pact in most of the years since the introduction of the euro. Member states have avoided sanctions because there was no qualified majority in EcoFin to impose them in the aftermath of the annulment of the sanctions against Germany and France. At the practical policy level, the regulatory framework was increasingly considered to be too weak to ensure the necessary harmonisation of economic policies (Nedergaard and Snaith 2015).

The cooperation on economic policy in the EU and EMU has therefore grown stronger in recent years. The increased cooperation has taken the shape of some comprehensive EU legal acts under the names 'Six Pack' and 'Two Pack', which involve automatic sanctions for violations of EMU rules, which in principle are more difficult to avoid than before, and through the decision that national budgets are to be discussed in the EcoFin before adoption - the so-called European semester. These initiatives included all EU member states, but only full EMU members can be fined. Finally, an intergovernmental agreement on the Fiscal Compact was adopted. The various reforms are refinements of the constitutive principles of the Maastricht Treaty's EMU as an economic constitution. Important non-political actors and experts in this regard are involved, and technocratic aspects of the reforms correspond to a strong belief in the powers of (economic) science (Biebricher and Vogelmann 2017a).

As an economic institution, the EMU was also established to keep inflation low. This is an important accession criterion and is included in the ECB statutes. The statute concerning low inflation was a strong demand from German decision-makers and reflected the statute of the German Bundesbank where it was introduced due to OL inspired decision-makers (Dullien and Guérot 2012). The ECB statutes state that the goal of the $E C B$ is primarily to independently ensure price stability, which is an expression of an OL recommendation on monetary policy coinciding with monetarism. The independent ECB corresponds to OL 'politics by rules' with autonomous, non-politicised, and technocratic decision-making about monetary policy. 
Even though central bank independence is not contrary to a Keynesian principles, most central banks in countries with a Keynesian-dominated economic policy have in practice been dependent on government decision-makers (Lijphart 1999). The attempts, albeit in practice often unsuccessful, to improve the EMU with a long-term economic perspective correspond to $\mathrm{OL}$, whereas Keynesians normally prefer the short-term perspective ('In the long run we are all dead').

At the level of regulative principles, the creation of Eurobonds and other forms of collective liability of member state debt in the aftermath of the Eurozone crisis have been rejected by Germany in particular. German decision-makers believe that an introduction at this time would increase uncertainty and reduce the credibility and, thereby, the 'politics by rules'basis of the European economy because of the inherent moral hazard problems associated with Eurobonds. Such a situation would contravene both the intergovernmentalist national interest of Germany by making the EU a 'transfer union', and the recommendations of OL. The rejection of joint liability is one of Eucken's seven principles for an economic and humane constitution (Eucken 1940). Table 4 on page 11 summarises the elements of $\mathrm{OL}$ and their operationalisation in relation to the EMU.

In conclusion, there are signs of $\mathrm{OL}$ influence at the level of constitutive principles in the EMU. At the level of practical policies (or regulative principles), however, the signs are less clear due to numerous exemptions resulting from short-sighted political influence.

\section{Conclusion}

This article operationalises OL into five constitutive elements plus policy practices. These operationalisations are then applied to CAP, EU competition policy, and the EMU as regards general OL 'politics by rules', the economic constitution, market construction, the role of consumers, the role of the state, and policy practices. This shows that there is some correspondence (albeit partial) between ideational OL and these three policies, and there is even less correspondence with respect to policy practice.

At the same time, there are also differences between the three analysed policy areas. Lowest on the correspondence scale is CAP. There is only a partial correspondence between the principles of $\mathrm{OL}$, the principles of the CAP, and the CAP practices. Next in line is the EMU. There are signs of OL influence at the level of constitutive principles in the EMU. At the level of practical policies (or regulative principles), however, the signs are less clear due to many exemptions because of short-sighted political influence.

We see the greatest correspondence in the area of competition policy. Here, there is strong correspondence between the constitutive principles of $\mathrm{OL}$ and the EU competition policy, which opens the way for influence. However, the correspondence is less strong when it comes to policy practices. This correspondence first became a significant reality after the Internal Market programme and globalisation processes of the 1990s.

Generally, I confirm the hypotheses proposed by Joerges (2017) and Oksala (2017) that OL was and remains an ideational influence of some importance - without exaggerating this influence - for European integration processes at both the conceptual or constitutive level and, albeit less so, the practical level. However, there are differences in terms of the degree of influence between the various policy areas. 


\section{Notes}

1. This is a translation of the key concept of ordoliberalism, namely Ordnungspolitik. The literal translation would be 'politics of ordering'; however, this sounds too authoritarian in many English-speaking ears compared to what is meant by the concept. Therefore, 'politics by rules' is better in that it gets closer to the meaning of the Ordnungspolitik concept.

2. See Bonefeld (2017) for an analysis hereof.

3. This section draws on Nedergaard (2013).

4. These two articles are traditionally the ones that are claimed to be the most directly ordoliberal (Fejø 2009).

5. This section draws on Nedergaard (2013).

6. EcoFin is the Council of Ministers for Economics and Finance Ministers of the EU.

\section{Acknowledgments}

I would like to thank the editor and two anonymous reviewers for helpful comments on earlier versions of this article.

\section{Disclosure statement}

No potential conflict of interest was reported by the author.

\section{References}

Akman, P., and H. Kassim. 2010. "Myth and Myth-making in the European Union: The Institutionalization and Interpretation of EU Competition Policy." Journal of Common Market Studies 48 (1): 111-132.

Biebricher, T., and F. Vogelmann, eds. 2017. The Birth of Austerity. London: Rowman \& Littlefield.

Biebricher, T., and F. Vogelmann. 2017a. "Introduction." In The Birth of Austerity, edited by T. Biebricher and F. Vogelmann, 1-22. London: Rowman \& Littlefield.

Böhm, F. 1937. "Die Ordnung der Wirtschaft als geschichtliche Aufgabe und rechtsschöpferiche Leistung, Stuttgart/Berlin: Kohlhammer." In The Birth of Austerity, edited by T. Biebricher and F. Vogelmann, 115-120. London: Rowman \& Littlefield. Translated in.

Bonefeld, W. 2017. The Strong State and the Free Economy. London: Rowman \& Littlefield.

Buch-Hansen, H., and A. Wigger. 2010. "Revisiting 50 Years of Market-making: the Neoliberal Transformation of European Competition Policy." Review of International Political Economy 17: 20-44. doi:10.1080/09692290903014927.

Clift, B. 2008. "The Fifth Republic at Fifty: The Changing Face of French Politics and Political Economy." Modern \& Contemporary France 16 (4): 383-398.

Commission. 2017. "Reflection Paper on the Future of EU Finances." Accessed 15 October 2017. https://ec.europa.eu/commission/sites/beta-political/files/reflection-paper-eu-finances_en.pdf

Dullien, S., and U. Guérot. 2012. "The Long Shadow of OL: Germany's Approach to the Euro Crisis." Paper ECFR/49. European Council of Foreign Relations.

Dyson, K. 2009. "German Bundesbank: Europeanization and the Paradoxes of Power." In Central Banks in the Age of the Euro, edited by K. Dyson and M. Marcussen, 131-160. Oxford: Oxford University Press.

Eucken, W. 1932. Weltwirschaftliches Archiv 36: 297-231 "Staatsliche Strukturwandlungen und die Krise des Kapitalismus." In The Birth of Austerity, edited by T. Biebricher and F. Vogelmann, 51-72. London: Rowman \& Littlefield. Translated in.

Eucken, W. 1940. Die Grundlagen der Nationalökonomie. Jena: Fischer.

Eucken, W. 1952. Grundsätze der Wirtschaftspolitik. Tübingen: J.C.B. Mohr. 
Eucken, W., F. Böhm, and H. Grossmann-Doerth. 1936. “'Unsere Aufgabe' (english: The Ordo Manifesto of 1936) in Frankfurter Zeitung, 29 November 1936." In edited by T. Biebricher and F. Vogelmann, 27-39. Translated in.

Fejø, J. 2009. EU-konkurrenceret. 4th ed. Copenhagen: DJøF Publishing.

Feld, L. P., E. A. Köhler, and D. Nientiedt. 2015. “Ordoliberalism, Pragmatism and the Eurozone Crisis." ERIS 2 (3): 48-61. doi:10.3224/eris.v2i3.23448.

Foucault, M. 2008. The Birth of Biopolitics: Lectures at the College De France, 1978-1979. Houndsmill: Palgrave Macmillan.

Gerber, D. J. 1998. Law and Competition in Twentieth Century Europe: Protecting Prometheus. Oxford: Oxford University Press.

Goldschmidt, N., and H. Rauchenschwandtner. 2007. "The Philosophy of Social Market Economy: Michel Foucault's Analysis of OL." Freiburger Diskussionspapiere zur Ordnungsökonomik, No. 07/4. University of Freiburg: Walter Eucken Institute.

Grant, W. 2018. "Brexit and Agriculture." In Handbook of Brexit Politics, edited by P. Diamond, P. Nedergaard, and B. Rosemond, 92-102. London: Routledge.

Haas, E. B. [1958] 2004. The Uniting of Europe. Political, Social, and Economic Forces, 1950-1957. Notre Dame, Indiana USA: University of Notre Dame Press.

Hayek, F. A. 1960. The Constitution of Liberty. Chicago: The University of Chicago Press.

Hix, S. 1999. The Political System of the European Union. Houndsmills Basingstoke, Hampshire: Palgrave Macmillan.

Hutchinson, T. W. 1981. The Politics and Philosophy of Economics: Marxians, Keynesians and Austrians. New York: New York University Press.

Joerges, C. 2017. "Europe after OL." In The Birth of Austerity, edited by T. Biebricher and F. Vogelmann, 197-220. London: Rowman \& Littlefield.

Lijphart, A. 1999. Patterns of Democracy: Government Forms and Performance in Thirty-six Democracies. New Haven: Yale University Press.

Nedergaard, P. 2006a. "Market Failures and Government Failures: a Theoretical Model of the Common Agricultural Policy." Public Choice 127 (3-4): 385-405. doi:10.1007/s11127-005-9000-1.

Nedergaard, P. 2006b. "The 2003 Reform of the Common Agricultural Policy: against All Odds or Rational Explanations?" Journal of European Integration 28 (3): 203-223. doi:10.1080/ 07036330600785749.

Nedergaard, P. 2013. "The Influence of OL in European Integration Processes: a Framework for Ideational Influence with Competition Policy and the Economic and Monetary Policy as Examples." Paper. University of Munich.

Nedergaard, P., and H. Snaith. 2015. "'As I Drifted on a River I Could Not Control": The Unintended Ordoliberal Consequences of the Eurozone Crisis." JCMS: Journal of Common Market Studies 53 (5): 1094-1109.

Nello, S. S. 2012. The European Union. Economics, Policies and History. 3rd ed. Birkshire: McGraw-Hill.

Oksala, J. 2017. "OL as Governmentality." In The Birth of Austerity, edited by T. Biebricher and F. Vogelmann, 181-196. London: Rowman \& Littlefield.

Rothbard, M. N. 1970. Man, Economy and State: a Treatise on Economic Principles. Vol. I and II. Los Angeles: Nash Publishing.

Vanberg, V. J. 2004. "The Freiburg School: Walter Eucken and OL." Paper 04/11. Freiburg: Walter Eucken Institut.

Walters, W., and J. H. Haahr. 2005. Governing Europe: Discourse, Governmentality and European Integration. London: Routledge.

Young, A. R. 2010. "The European Policy Process in a Comparative Perspective." InPolicy-Making in the European Union. Series: New European Union Series, edited by H. Wallace, M. A. Pollack, and A. R. Young, 45-68. Oxford, UK: Oxford University Press. 